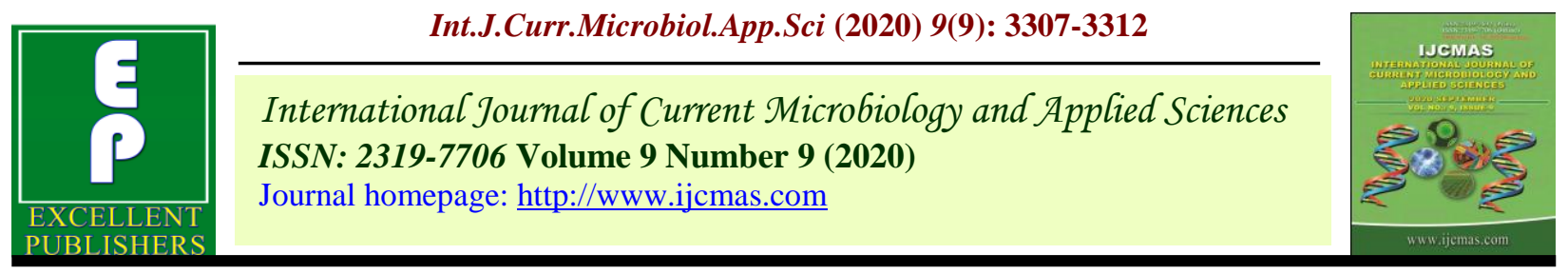

Original Research Article

https://doi.org/10.20546/ijcmas.2020.909.411

\title{
Effect of Different Levels of NPK and Zinc on Physico-chemical Properties of Soil, Growth and Yield of Pea [Pisum sativum L.] Var. Bliss-101
}

\author{
J. R. Rohith*, Arun Alfred David and Tarence Thomas
}

Department of Soil Science and Agricultural Chemistry, Sam Higginbottom University of Agriculture, Technology and Sciences, Prayagraj- 211 007, Uttar Pradesh, India

*Corresponding author

\section{A B S T R A C T}

\begin{tabular}{l} 
Ke y w o r d s \\
$\begin{array}{l}\text { Zinc, NPK } \\
\text { and Pea }\end{array}$ \\
Article Info \\
$\begin{array}{l}\text { Accepted: } \\
\text { 24 August } 2020 \\
\text { Available Online: } \\
\text { 10 September } 2020\end{array}$ \\
\hline
\end{tabular}

A field experiment was conducted at department of soil science and agricultural chemistry, SHUATS, Prayagraj, during rabi 2019 on loamy sand soil. The experiment consisted of 9 treatments combinations which were replicated thrice and laid out in a RBD of three levels of NPK (0\% NPK, $50 \%$ NPK and $100 \%$ NPK), three levels of $\mathrm{Zn}\left(0 \% \mathrm{ZnSO}_{4}, 50 \%\right.$ $\mathrm{ZnSO}_{4}$ and $\left.100 \% \mathrm{ZnSO}_{4}\right)$. The results showed that progressive increase in the growth of (Plant height $(\mathrm{cm})$, number of leaves per plant, number of branches) and in yield, number of pods per plant, number of seed per pod, and Pod yield ( $\left.\mathrm{q} \mathrm{ha}^{-1}\right)$ in application of $\mathrm{T}_{8}(\mathrm{NPK}$ $100 \%, \mathrm{Zn} 100 \%$ 40: 80:40 Kg NPK+20 Kg Zn ha ${ }^{-1}$ ) of Pea [Pisum sativum L.] were found to be the best treatment combinations.

\section{Introduction}

Pea is one of the six major pulse crop cultivated globally and it is the second highest yielding legume in the world after common bean (Phaseolus vulgaris L.) (FAO, 2010). Pea (Pisum sativum L.) is one of the world's oldest domesticated crops. In addition, it is also important vegetable crop due to its high nutritive value, particularly proteins 7.2g/100g (Singh et al., 2007). In major part of the world and also consumed as green vegetables (whole pods or immature seed) in Asian countries as well as dry seed in Europe, Australia, America and Mediterranean regions (Ghafoor et al., 2008). Green peas are eaten cooked as a vegetable, and marketed fresh, canned or frozen while ripe dried peas are used whole, split or made into flour. Field pea is an important pulse crop in India, covering an area of 0.498 million ha with production of 4.81million tonnes (Anonymous, 2017).

In 2017, a total of 8,141,031 hectares of field pea were harvested globally, with the top producers consisting of Canada, Russia, China, India, and the United States (FAOSTAT, 2019) however, this is only a minimal fraction compared to cereal production. Cultivated land acreage for field pea and other pulses has been in steady decline over the past 30 years (Stagnari et al., 2017). Average yields have increased about 70-84\% since 1974 for staple legumes, such 
as soybean, lentil, chickpea, and groundnut; in contrast, yields for field pea have increased but resulted in no net production gains due to decreasing land acreage (Foyer et al., 2016). The minimal expansion of pulses in agriculture is due to smaller and unpredictable yields, caused by susceptibility to environmental factors, and has resulted in a less-developed global market with decreased profits, disincentivizing farmers from using pulses for income while policymakers focus more attention and resources on cereals in developing countries (Foyer et al., 2016; Stagnari et al., 2017).

Therefore, increase in quality seed production of pea is the need of the time to boost up the production of crop Improper farming practices such as monocropping, imbalanced fertilization, poor soil organic matter management, soil contamination, soil compaction, mining of soil nutrients, water logging, depletion of ground water, decline in soil biodiversity and changing pest and disease complex and application of imbalanced NPK fertilizers ratio of 7.9:3:1 as against normal values of $4: 2: 1$ are the major factors for soil degradation (Purohit and Gehlot, 2006). Looking the adverse effects of fertilizers and chemicals stress is being given to promote organic farming. It is estimated that plant nutrients (NPK) addition during 2020 will be removal of 37.46 million tonnes nutrients by crops for which nutrient additions generally fall short of requirement i.e., 7.86 million tonnes.

In this context, the projected (2025) availability of plant nutrients trapable from organic sources is 7.75 million tonnes (Purohit and Gehlot, 2006). Besides, there is growing demand for organic produce which gets higher remunerative price even if yields are lower. Most of people believe that organic farming is the right choice for the long term future of the earth.
Zinc plays an outstanding role in synthesis of chlorophyll, protein and also regulates water absorption. Moreover, it also play role in carbohydrates metabolism and activation of various enzymes which help in inducing alkalinity tolerance in crops by enhancing $\mathrm{Na} / \mathrm{K}$ and $\mathrm{Na} / \mathrm{Ca}$ ratio.

The deficiency of Zinc is most widely spread as reported. (Thakkar et al., 2005) Zinc deficiency is particularly reported from Punjab, tarai area of U.P., some parts of Haryana, Western U.P. and Delhi. If Zinc deficiency is acute, a dose of $50 \mathrm{~kg} \mathrm{ZnSO}_{4}$ ha $^{-}$ 1 recommended. The Zinc is an essential component required in the biosynthesis of plant hormone viz. Indole acetic acid (IAA) and is a component of a variety of enzymes such as carbonic anhydrates, alcohol dehydrogenises etc. Zinc plays a role in the synthesis of nucleic acid and protein. It also helps in the utilization of phosphorus and nitrogen along with physiology of seed formation. The Zinc also maintains the semipermeability of the cell membrane.

\section{Materials and Methods}

\section{Soil sampling}

The soil of experimental area falls in order of Inceptisol and in experimental plots is alluvial soil in nature. The soil samples randomly collect from five different sites in the experiment plot prior to tillage operation from a depth of $0-15 \mathrm{~cm}$. The size of the soil sample reduce by conning and quartering the composites soil sample is air dry and pass through a $2 \mathrm{~mm}$ sieve by way of preparing the sample for physical and chemical analysis. The experimental details are given below under different heading:

\section{Design and treatment}

The experiment consisted of 9 treatments combinations which were replicated thrice 
and laid out in a factorial RBD (R.A. Fisher) of three Levels of NPK (0 \% NPK, $50 \%$ NPK and $100 \% \mathrm{NPK})$, three level of $\mathrm{Zn}(0 \%$ $\mathrm{ZnSO}_{4}, 50 \% \mathrm{ZnSO}_{4}$ and $\left.100 \% \mathrm{ZnSO}_{4}\right)$.

\section{Experimental sites}

The experiment was conducted on the research farm of department of Soil Science and agricultural chemistry, Sam Higginbottom University of Agriculture, Technology and Sciences, Prayagraj which situated six km away from Prayagraj city on the right bank of yamuna river, the experimental site is located in the sub tropical region with $25^{\circ} \mathrm{N}$ latitude $81.50^{\circ} \mathrm{E}$ longitude and 95 MS Laltitude.

\section{Fertilizer application}

The fertilizers were applied in each plot according to treatment combinations. $\mathrm{T}_{0^{-}}$ Control (Absolute control), $\mathrm{T}_{1}-\mathrm{NPK} 0 \%, \mathrm{Zn}$ $50 \% 10 \mathrm{Kg} \mathrm{Zn} \mathrm{ha}^{-1}, \mathrm{~T}_{2}$ - NPK $0 \%$, Zn $100 \%$ $20 \mathrm{Kg} \mathrm{Zn} \mathrm{ha}{ }^{-1}, \mathrm{~T}_{3}-\mathrm{NPK} 50 \%$, Zn $0 \%$ 20:40:20 Kg NPK ha ${ }^{-1}, \mathrm{~T}_{4}$ - NPK $50 \%$, Zn 50 $\%$ 20:40:20 Kg NPK+10Kg Zn ha ${ }^{-1}, \mathrm{~T}_{5^{-}}$NPK $50 \%, \mathrm{Zn} 100 \%$ 20:40:20 Kg NPK + $20 \mathrm{Kg}$ $\mathrm{Zn} \mathrm{ha}^{-1}, \mathrm{~T}_{6}$-NPK $100 \%$, Zn 0 \% 40:80:40 Kg NPK ha ${ }^{-1}, \mathrm{~T}_{7}$ - NPK $100 \%$, Zn $50 \%$ 40:80:40 $\mathrm{Kg} \mathrm{NPK}+10 \mathrm{Kg} \mathrm{Zn} \mathrm{ha}^{-1}, \mathrm{~T}_{8}$ - NPK $100 \%$, Zn $100 \%$ 40:80:40 Kg NPK + $20 \mathrm{Kg} \mathrm{Zn} \mathrm{ha}^{-1}$ was given in equal quantity to each plot which was calculated on the basis of general recommendation for pea as $40 \mathrm{Kg}, 80 \mathrm{Kg}, 40$ $\mathrm{Kg} \mathrm{ha}^{-1}$ was supplied.

Table.1 Interaction effect of different treatment combination of NPK and Zinc fertilizers on pre and post harvest observations

\begin{tabular}{|c|c|c|c|c|c|c|}
\hline Treatments & $\begin{array}{c}\text { Plant } \\
\text { height } \\
\text { (cm) }\end{array}$ & $\begin{array}{c}\text { Number of } \\
\text { leaves } \\
\text { plant }^{-1}\end{array}$ & $\begin{array}{c}\text { Number of } \\
\text { Branches } \\
\text { plant }^{-1}\end{array}$ & $\begin{array}{c}\text { Number } \\
\text { of Pods } \\
\text { plant }^{-1}\end{array}$ & $\begin{array}{l}\text { Number of } \\
\text { Seed per pod } \\
\text { (g) }\end{array}$ & $\begin{array}{c}\text { Pod } \\
\text { Yield } \\
\left(\mathbf{q} \text { ha }^{-1}\right)\end{array}$ \\
\hline $\mathbf{T}_{\mathbf{0}}$ & 71.41 & 134.50 & 23.93 & 17.40 & 7.40 & 84.40 \\
\hline $\mathbf{T}_{1}$ & 66.94 & 172.20 & 40.53 & 22.53 & 8.47 & 84.43 \\
\hline $\mathbf{T}_{2}$ & 64.47 & 231.67 & 38.13 & 23.20 & 8.67 & 90.76 \\
\hline $\mathbf{T}_{\mathbf{3}}$ & 65.39 & 140.67 & 40.40 & 24.13 & 9.03 & 89.83 \\
\hline $\mathbf{T}_{4}$ & 65.42 & 135.00 & 41.20 & 22.33 & 9.13 & 94.46 \\
\hline $\mathbf{T}_{5}$ & 72.29 & 211.93 & 44.53 & 24.53 & 9.33 & 101.73 \\
\hline $\mathbf{T}_{6}$ & 69.57 & 147.60 & 36.60 & 19.07 & 8.00 & 97.46 \\
\hline $\mathbf{T}_{7}$ & 60.56 & 203.27 & 43.93 & 23.33 & 9.13 & 99.56 \\
\hline $\mathbf{T}_{8}$ & 68.62 & 259.53 & 67.40 & 28.00 & 9.47 & 103.6 \\
\hline F- test & $\mathrm{S}$ & S & S & S & $S$ & S \\
\hline S. Ed. $( \pm)$ & 1.998 & 7.017 & 2.648 & 1.461 & 0.52 & 2.16 \\
\hline C. D. $(P=0.05)$ & 4.123 & 14.483 & 5.466 & 3.016 & 1.074 & 4.459 \\
\hline
\end{tabular}

\section{Results and Discussion}

Data presented in table 1 showed that application of $\mathrm{T}_{8}$ (NPK $100 \%$, Zn $100 \%$ 40:80:40 Kg NPK+20 Kg Zn ha ${ }^{-1}$ ) significantly enhanced the pre and post harvest of pea observations. The significantly highest plant height $(68.62 \mathrm{~cm})$, Number of leaves per plants (259.53), number of branches per plant (67.40), number of pods plant ${ }^{-1}$ (28.00), number of Seed per pod (9.47), and Pod Yield (q ha ${ }^{-1}$ ) (103.60) of pea were observed with application of (NPK $100 \%, \mathrm{Zn} \mathrm{100 \%} \mathrm{40:80:40} \mathrm{Kg} \mathrm{NPK} \mathrm{+} 20 \mathrm{Kg} \mathrm{Zn}$ $\left.\mathrm{ha}^{-1}\right)$. 
As the favourable effect of $\mathrm{N}$, and indispensable elementary constituent of numerous organic compounds of general importance (amino acids, protein, and nucleic acid), which are needed in the formation of protoplasm and new cells, and thus increased fresh and dry weight of different parts of plant (Edmond et al., 1981). In addition, Bidwell (1979) showed that phosphorous plays a vital role in the enzyme system for the energy transform in photosynthesis and respiration and then increased plant growth. Furthermore, El- Seifi et al., (2013) found that potassium had a crucial role in the energy status of the plant, translocation and storage of assimilates and maintenance of tissue water relation, consequently, $\mathrm{N}, \mathrm{P}$ and $\mathrm{K}$, together promoted the plant growth characters.

Increase in plant height in response to higher $\mathrm{N}$ levels has been confirmed by Akbar et al., (2002) and Rasheed et al., (2004). Increase in plant height due to more $\mathrm{N}$ may be attributed to more vegetative development that resulted in increased mutual shading and internodal extension.

The favourable effect of applied zinc on these characters may be ascribed to its catalytic or stimulatory effect on most of the physiological and metabolic processes of plants. Zinc performs many catalytic functions in the plant besides transformation of carbohydrates, chlorophyll synthesis and protein synthesis Kelarestaghi et al., (2007). Besides this, zinc also enhances the absorption of $\mathrm{N}, \mathrm{K}$ and $\mathrm{Zn}$ (Ashoka et al., 2008), and decreases the absorption of $P$ (Khan et al., 2007 and Alam et al., (2000). Concerning the effects of treatments on the studied flowering traits, the results of the two growing seasons indicated that Farmyard manure + NPK Fertilizer significantly, delayed flowering and increased fruit set percentage. Such results might be attributed to the stimulation effects of $\mathrm{N}, \mathrm{P}$ and $\mathrm{K}$ fertilizer on the vegetative growth characters that consequently, resulted in delaying the flowering and increasing fruit set percentage. Achakzai (2012) have also reported likewise. Number of branches per plant was significantly higher with (NPK $100 \%$, Zn $100 \%$ 40:80:40 Kg NPK + $20 \mathrm{Kg} \mathrm{Zn} \mathrm{ha}{ }^{-1}$ ). Also similar results with Andrzejewska, J. (2002) reported that the increase of seed yield affected by microelement fertilization resulted from the increase in the number of pods per plant and to a lower extent of the increase in the number of seeds per pod. Also Choudhary (2006) found that zinc fertilization in clusterbean up to $5 \mathrm{~kg} \mathrm{ha}{ }^{-1}$ registered significant enhancement in pods per plant, seeds per pod, seed, straw and biological yields over preceding levels. However, similar results confirmed by Sharar et al., (2003) have also stated positive influence of nitrogen and zinc on this trait. The positive yield forming effect of foliar application of zinc (Wronska et al., 2007; Potrycki 2011). The maximum grain yield (37.78 $\left.\mathrm{q} \mathrm{ha}^{-1}\right)$ was observed by the application of $\mathrm{T}_{8}=@ 100 \%$ $\mathrm{NPK}+100 \% \mathrm{Zn}$ and the lowest grain yield value (17.55 q ha ${ }^{-1}$ ) was observed in treatment $\mathrm{T}_{0}=@ 0 \% \mathrm{NPK}+0 \% \mathrm{Zn}$. Maize grain yield increased as a result of zinc application which has also been reported by Behera et al., (2008).

In conclusion the present investigation, it was apparent that application of NPK and $\mathrm{Zn}$ fertilizers in treatment $\mathrm{T}_{8}(\mathrm{NPK} 100 \%, \mathrm{Zn}$ $100 \%$ 40:80:40 Kg NPK + $20 \mathrm{Zn} \mathrm{ha}^{-1}$ ) was found on maximum plant height, number of leaves per plant, number of branches, number of pods per plant, number of seed per pod and pod yield than other treatment combinations. All observations recorded are significant. Thus, it can be concluded that different levels of NPK and $\mathrm{Zn}$ fertilizers improved soil available nutrient, increased all mentioned observations. However, pod yield increased and also among the treatments $\mathrm{T}_{8}$ recorded the 
best treatment which increased the availability of nutrient and influenced on plant parameters of pea as well.

\section{Acknowledgement}

The authors are grateful to the Hon'ble Vice chancellor SHUATS, Department of Soil Science and Agricultural Chemistry, Naini Agriculture Institute, for taking their keen interest and encouragement to carry out the research work.

\section{References}

Achakzai A.K.K. (2012) Effect of various levels of nitrogen fertilizer on some vegetative growth attributes of pea (Pisum sativum L.) cultivar. J Bot.; 44(2): 655-659.

Akbar H, Miftahullah MT, Jan A Jan, (2002) Ihsanullah. Yield potential of sweet corn as influenced by different levels of nitrogen and plant population. Asian $\mathrm{J}$ Pl. Sci.; 1(6): 631-633.

Alam, S.M., Zafar, I. and Latif, A. (2000) Effect of $\mathrm{P}$ and $\mathrm{Zn}$ application by fertigation on phosphorus use efficiency and yield of wheat. International Journal on Agricultural Research and Extension, 3(2):17-20.

Andrzejewska, J. (2002) Yield and agronomic conditions of [4] nodulation in different pea varieties (Pisum sativum L.). Rozp. Hab., 105. Bydgoszcz. 91.

Anonymous, (2017) Horticultural Statistics at a Glance (2017) Horticulture Statistics Division Food and Agriculture Organization. Food Agriculture Organization Database. http://www.faostat.fao. Org. 2010.

Ashoka, Mudalagiriyappa, P. and Desai, B.K. (2008) Effect of micronutrients with or without organic manures on yield of baby corn-chickpea sequence. Karnataka Journal of Agricultural
Sciences, 21(4):485-487.

Behera, S. K. Dhyan Singh Dwivedi, B. S. Sarjeet Singh Kumar, K. and Rana, D. S. (2008) Distribution of fractions of zinc and their contribution towards availability and plant uptake of zinc under long-term maize (Zea mays L.)wheat (Triticum aestivum L.) cropping on an Inceptisol. Australian Journal of Soil Research. 46: 1, 83-89.

Bidwell, R. G. S., (1979) Plant physiology.2nd ed. Mac Millan Publishing Co. INC, New York.

Choudhary, M. (2006) Response of clusterbean [Cymopsis tetragonoloba (L.)Taub] to sulphur and zinc fertilization. M.Sc. (Ag.) Thesis, Rajasthan Agricultural University, Bikaner.Department of Agriculture, Cooperation \& Farmers Welfare Ministry of Agriculture \& Farmers Welfare Government of India, pp. 56.

Edmond, J.B., T.L. Senn, F.S. Zndenws and R.G. Halfacre, (1981) Fundamentals of Horticulture.Published Tata NcGrawHill Publishing Co. Limited Indian.

El- Seifi, S.K., M.A. Hassan and A.M. ElSaeed, (2013) The effect of organic, mineral and biofertilization on growth, yield and chemical composition of pigeon pea (Cajanus cajan) under Ismailia region conditions. J. Plant Production, Mansoura Univ.,

FAOSTAT. (2019) http://www.fao.org/ faostat/en/\#data/QC.

Foyer, C. H., Lam, H.-M., Nguyen, H. T., Siddique, K. H. M., Varshney, R. K., Colmer, T. D., (2016) Neglecting legumes has compromised human health and sustainable food production. Nat. Plants 2 (8), 16112. doi: 10.1038/nplants.2016.112

Ghafoor A, Arshad M. (2008) Seed protein profiling of Pisum sativum L. germplasm using sodium dodecyl sulphate polyacrylamide gel 
electrophoresis (SDS-PAGE) for investigation of biodiversity. Pak. J Bot. 40(6): 2315-2321.

Kelarestaghi, B.K., Novrihasseini, M., Madani, H. and Khoshaui. (2007) Investigation of zinc uptake efficiency in six variety of Franian bread wheat. Islamic Azad University of Mashhad, 13.

Khan, U.M., Qasim, M and Khan, I. (2007) Effect of $\mathrm{Zn}$ fertilizer on rice grown in different soils of Dera Ismail khan. Sarhad Journal of Agriculture, 23(4).

Potarzycki J. (2011) Effect of magnesium or zinc supplementation at the background of nitrogen rate on nitrogen management by maize canopy cultivated in monoculture. Plant Soil Environ. 57: 19-25.

Purohit S.S., and Gehlot D., (2006) In 'Trends in Organic Farming', Agrobios India, Jodhpur, Rajasthan, pp.438

Rasheed M, Ali H, Mahmood T. (2004) Impact of nitrogen and sulfur application on growth and yield of maize crop. Pak. J Sci. Res15(2):153157.

Sharar MS, Ayub M, Nadeem MA, (2003) Ahmad N. Effect of different rates of nitrogen and phosphorus on growth and grain yield of maize. Asian J Pl. Sci.
2(3):347-349. 32.

Singh J.D., Kumar B, Singh J.P. (2007) Genetic variability, heritability and character association in dwarf field pea (Pisum sativum L.). Progress. Agric. 7(1/2):102-104.

Stagnari, F., Maggio, A., Galieni, A., Pisante, M. (2017) Multiple benefits of legumes for agriculture sustainability: an overview. Chem. Biol. Technol. In Agric. 4 (2), 2.doi: 10.1186/s40538016-0085-1.

Thakkar, D.P, Smile and M. (2005) Reclamation of Zinc. Journal of Indian society of Soil Science.2005, 36:2, 311312 ref.

Urbano G.P., Arnda, Gomez E.V. (2003) Nutrition evaluation of pea (Pisum sativum L.) protein diets after mild hydrothermal treatment and with and without added phytase. J Agric. Food Chem.; 51(8): 2415-2420.

Wronska M, Grzebisz W, Potarzycki P, Gaj R. (2007) Maize response to nitrogen and zinc fertilization. Grain yield and elements of yield structure. Fragmenta Agronomica. 22: 390-399.

Zohary D, Hopf M. (1973) Domestication of pulses in the old world. Sci.; 182:887894.

\section{How to cite this article:}

Rohith, J. R., Arun Alfred David and Tarence Thomas. 2020. Effect of Different Levels of NPK and Zinc on Physico-chemical Properties of Soil, Growth and Yield of Pea [Pisum sativum L.] Var. Bliss-101. Int.J.Curr.Microbiol.App.Sci. 9(09): 3307-3312.

doi: https://doi.org/10.20546/ijcmas.2020.909.411 